\title{
Depressivitet og røyking - En prospektiv panelstudie blant ungdom i Hordaland
}

\author{
Kjersti Strønstad, Leif Edvard Aarø, Jørn Hetland og Bente Wold \\ Hemil-senteret, Universitetet i Bergen, Christiesgt. 13, 5015 Bergen \\ Korrespondanse: Leif Aarø, Telefon: 55582606 Telefax: 55589887 e-post: leif.aaro@psych.uib.no
}

\begin{abstract}
SAMMENDRAG
Flere tidligere studier blant ungdom (både tverrsnittsundersøkelser og prospektive panelundersøkelser) har vist at ungdom som er deprimerte eller som skårer høyt på skalaer som måler depressivitet har en økt sannsynlighet for å røyke. Om depressivitet er en medvirkende årsak til at ungdom røyker er imidlertid uklart. Strukturelle ligningsmodeller som kan bidra til å belyse spørsmålet om kausalitet brukes sjelden. I den foreliggende undersøkelsen har vi benyttet data fra en prospektiv panelundersøkelse blant ungdom i Hordaland. Også i dette datamaterialet finner vi tverrsnitts-assosiasjoner mellom depressivitet og røyking. Sammenhengene er ikke signifikant forskjellige for gutter og jenter. Ved bruk av data fra tre tidspunkt (1992, 1993 og 1995) utvikles det to strukturelle ligningsmodeller $(n=551)$ som begge tyder på at kausaliteten hovedsakelig går fra depressivitet til røyking. Sammenhengene er relativt svake, men de synes å øke noe med alder. Modellene forblir uendret selv når det kontrolleres for foreldres røykevaner og foreldres sosioøkonomiske status. Depressivitet har trolig langt mindre å bety for ungdoms røykevaner enn faktorer som tilgjengelighet på tobakk og sosial påvirkning. Depressivitet er sannsynligvis av større betydning som en barriere i forbindelse med å få voksne til å slutte å røyke enn som en faktor en må ta hensyn til når en planlegger forebyggende tiltak overfor ungdom.
\end{abstract}

\section{Strønstad K, Aarø LE, Hetland J, Wold B. Depressiveness and smoking - A prospective study among adolescents in Hordaland County. Nor J Epidemiol 2002; 12 (3): 221-230.}

\section{ENGLISH SUMMARY}

A number of studies (cross sectional as well as prospective longitudinal studies) have shown positive associations between scores on scales measuring depressive tendencies and smoking habits among adolescents. Still it is not clear to what extent depressive tendencies can be regarded as a causal factor in the process of smoking initiation. Structural equation modelling, which is a most useful tool when testing out causal models, are seldom applied. The present analyses are based on data from a prospective panel study carried out among a cohort of adolescents from one county in Western Norway. Data collected in 1992, 1993, and 1995 (the students were 15 years old in 1992) are used. Significant cross-sectional associations between depressive tendencies and smoking habits are found on all three measurement occasions. None of the associations are significantly different for boys and girls (no significant interaction effects). Two structural equations models with approximately the same levels of fit are developed. Both models (one cross-lagged and one with simultaneous regression) indicate that the causal direction goes from depressive tendencies to smoking. The regression coefficients are rather moderate, but the impact of depressive tendencies on smoking habits seems to increase with age. When controlling for parents' smoking habits and parents' socioeconomic status the models remain unchanged. Depressive tendencies are probably less important in the process of smoking initiation among adolescents than it is as a barrier for adult smokers who try to quit. As far as adolescent smoking is concerned, social influences as well as availability of cigarettes are obviously more important factors to take into account when planning tobacco control measures.

\section{INNLEDNING}

Jo mer en vet om årsakene til at ungdom begynner å røyke, desto bedre grunnlag har en for å utvikle effektive forebyggende tiltak. Forskning om årsaker til at ungdom begynner å røyke har foregått helt siden røykingens helseskadelige virkninger ble dokumentert $\mathrm{i}$ 1950-årene. En har sett på personfaktorer som kunnskaper og oppfatninger om tobakkens skadevirkninger, holdninger, mestringsforventninger, resultatforventninger, intensjoner og personlighetstrekk. Videre har en undersøkt omgivelsesfaktorer som påvirkninger fra foreldre og jevnaldrende, reklame, prisen på tobakksprodukter og tilgjengeligheten av tobakk. En har også unders $ø$ kt hvordan tobakksbruken varierer med demografiske faktorer som for eksempel sosioøkonomisk status og med ungdoms forhold til skole og utdanning. Endelig har en også studert hvordan tobakksrøyking 
korrelerer med andre helserelaterte atferdsmønstre. På alle disse områdene har en funnet viktige risikofaktorer for røyking blant ungdom. Selv om mye av forskningen har vært basert på tverrsnittsstudier, foreligger det også et betydelig antall undersøkelser med et prospektivt, longitudinelt design (1).

De siste årene har det kommet en del studier blant voksne som viser hvordan tobakksrøyking og nikotinavhengighet henger sammen med depressivitet og depresjoner. Flere tverrsnittsundersøkelser blant befolkningsutvalg $(2,3)$ og i kliniske utvalg (4) har vist en slik sammenheng. Kliniske studier har vist at det er langt mer røyking blant pasienter med depresjon enn $\mathrm{i}$ befolkningen ellers (5). Undersøkelser har dessuten vist at det blant deprimerte personer er langt færre som slutter å røyke enn blant ikke-deprimerte $(2,6)$.

Også tverrsnittsundersøkelser blant ungdom viser at det er mest røyking blant de som skårer høyt på skalaer som måler depressivitet (7-12). Costello og medarbeidere (13) fant at tobakksrøyking var langt mer prevalent blant ungdom med depresjon enn blant ungdom som ikke hadde noen diagnose. Noen studier viser at sammenhengen mellom depressivitet og røyking er sterkere blant jenter enn blant gutter (14-16). Acierno og medarbeidere (17) hevder også å ha funnet dette, men de statistiske analysene de baserer denne konklusjonen på er ikke overbevisende. Det foreligger en enkelt studie som har vist at sammenhengen er til stede for gutter, men ikke blant jenter (18). Utilstrekkelig statistisk analyse av dataene gjør at heller ikke dette kan betraktes som noe sikkert funn. Andre undersøkelser tyder på at styrken på sammenhengen mellom røyking og depressivitet blant ungdom varierer med alder, med forekomst av atferdsproblemer, med grad av urbanisering og med hvordan en definerer røyking. Disse studiene er grundigere presentert og drøftet av Strønstad (19). En studie blant ungdom fra Slovenia $(n=2111)$ viste at sammenhengen mellom røyking og depressivitet var svært svak og ikke statistisk signifikant (20).

En undersøkelse blant norske ungdomsskoleelever $(n=177)$ viste en sammenheng mellom røyking og psykiatriske symptomer (herunder depressive symptomer) blant både gutter og jenter. Forfatterne hevder sammenhengen er "mest markert" blant jenter, men sammenhengen målt med Kendalls tau er omtrent like stor for begge kjønn (0,29 blant gutter og 0,30 blant jenter) (21).

En statistisk assosiasjon mellom depressivitet og tobakksrøyking funnet $\mathrm{i}$ tverrsnittsstudier er selvsagt ingen sikker bekreftelse på at det foreligger en årsakssammenheng. Det kan godt tenkes at begge deler kan skyldes bakenforliggende årsaksfaktorer, for eksempel at barn som utsettes for ulike former for sosiale belastninger under oppveksten (dårlig familieøkonomi, arbeidsledige foreldre, rusproblemer $\mathrm{i}$ familien etc.) har både en økt risiko for å begynne å røyke og en økt risiko for å utvikle depressive tendenser og depresjon. Også personlighetsvariabler kan tenkes å fungere som slike "confoundere". Det foreligger en studie som bekrefter at sammenhengen mellom depresjon og røyking delvis kan forklares av felles, bakenforliggende risikofaktorer (10). Kendler og medarbeidere (22) mener at genetiske faktorer disponerer både for depresjoner og røyking.

For å kunne si noe mer om mulige årsakssammenhenger er det en fordel med data fra prospektive, longitudinelle undersøkelser. Så sent som i 1995 ble nettopp dette kommentert i en artikkel i Epidemiologic Reviews (23):

Several studies have found that depression is related to smoking among adolescents and young adults. ... However, we are aware of no data that show a higher rate of smoking initiation or a lower rate of cessation among depressed than nondepressed adolescents.

Imidlertid foreligger det nå flere longitudinelle studier blant ungdom der det er vist at depresjoner eller høy skåre på skalaer som måler depressivitet predikerer røyking på senere tidspunkt (24-34).

Blant de studiene som analyserer sammenhengen mellom depresjon og depressivitet på den ene siden og røykevaner og nikotinavhengighet på den andre, er det imidlertid ikke alle som analyserer data optimalt med tanke på å belyse spørsmålet om hva som er årsak og hva som er virkning. Noen nøyer seg med å se om depressivitet på ett tidspunkt predikerer røyking på et senere tidspunkt uten at de kontrollerer for røyking på det tidligste tidspunktet $(24,29)$. Slike analyser gir ikke særlig mer informasjon om kausalitet enn analyser av tverrsnittsdata.

Men i noen studier er det undersøkt hvordan depressivitet på ett tidspunkt henger sammen med etterfølgende røykeintiering. Et slikt eksempel er studien av Escobedo og medarbeidere (28) der de på et stort utvalg ungdommer i alderen 12-18 år viser at høy skåre ved baseline på en skala som måler depressivitet var assosiert med økt risiko for å begynne å røyke. Oppfølgingsundersøkelsen ble gjort etter 4 år. Blant de som skåret lavt på depressive symptomer var andelen som begynte å røyke (etter kontroll for en del andre variabler) $12,9 \%$, mot $19,0 \%$ blant de som skåret høyt på depressive symptomer. Denne sammenhengen karakteriserer forfatterne som svak. Også Patton og medarbeidere (31) har sett på betydningen av depressivitet for røykeinitering, men de konkluderer med at det er kombinasjonen av det å ha venner som røyker og depressivitet som forer til at flere begynner. MillerJohnson et al. (35) hevder på bakgrunn av en studie blant afrikansk-amerikanske skoleungdommer at det er kombinasjonen av depressivitet og atferdsproblemer (conduct disorder) som gir en økt risiko for å begynne å røyke. Killen og medarbeidere (30) finner i en prospektiv studie blant ungdom at høy skåre på en skala som måler symptomer på depresjon predikerer det å ha prøvd å røyke, men bare blant gutter.

Wang et al. (33) ser på tidsforskjøvne assosiasjoner (cross lagged associations) mellom røyking og depressivitet på ett tidspunkt og de samme variablene 4 år se- 
nere. De finner at de to tidsforskjøvne sammenhengene målt med Kendalls tau begge var statistisk signifikante og omtrent like store. Dette tolker de som en støtte til antakelsen om at det eksisterer en gjensidig påvirkningsprosess. På bakgrunn av en latent vekstkurveanalyse der de kontrollerer for et stort antall psykososiale prediktorer trekker Windle \& Windle (34) den konklusjon at vedvarende (persistent) høy skåre på depressive symptomer predikerer økt røyking, samtidig med at vedvarende høyt forbruk av sigaretter predikerer depressive symptomer. Også dette tas til inntekt for at det eksisterer en gjensidig påvirkningsprosess mellom depressivitet og røyking. Begge disse studiene viser at sammenhengene er nokså svake. Brown et al. (26) analyserte data fra en prospektiv studie (oppfølging etter ett år) blant ungdommer i alderen 14-18 år $(n=1709)$. De fant at røyking predikerte depresjon (major depressive disorder) og at det å ha hatt en depresjon predikerte det å begynne å røyke. Også Breslau og medarbeidere (25) finner holdepunkter for at kausaliteten går begge veier.

Choi og medarbeidere (36) har analysert data fra en større amerikansk undersøkelse $(n=6863)$ blant ungdommer i alderen 12-18 år og finner at røyking på ett tidspunkt har sammenheng med det å utvikle depressive symptomer fire år senere.

Den foreliggende forskningen omkring sammenhengen mellom røyking og depressivitet gir ikke noe enkelt og entydig bilde. En rekke prospektive studier blant ungdom viser likevel at depressive episoder og høy skåre på depressivitet begge deler predikerer det å begynne å røyke. Noen ganger bekreftes også den motsatte retningen på sammenhengen, altså at røyking predikerer depresjoner og depressivitet. Atter andre studier tyder på at sammenhengen modereres av tredjevariabler.

Når forskerne skal forklare hvorfor depressivitet kan føre til at noen begynner å røyke, tyr de gjerne til det som kalles "selvmedikasjonshypotesen" (37). En antar at røyking hos mange fungerer som et middel til å redusere negativ affekt, og at dette motiverer til å prøve å røyke, til å fortsette å røyke når en først har prøvd, og til å opprettholde røykingen når en er blitt vanerøyker.

I den foreliggende artikkelen skal vi se på sammenhengen mellom depressivitet og røyking. Vi er særlig opptatt av å finne holdepunkter for retningen på kausaliteten, med andre ord om det er røyking som predikerer depressivitet eller om det er depressivitet som predikerer røyking.

\section{Metode}

Dataene som er brukt i denne artikkelen stammer fra forskningsprosjektet "Voksen i år 2000" som er en prospektiv longitudinell undersøkelse blant ungdom. Undersøkelsen omfattet et representativt utvalg elever fra skoler i Hordaland. Alle skoler som ble trukket ut sa ja til å være med i undersøkelsen. Første datainn- samling ble gjennomført i 1990 da elevene gikk i 7 . klasse og gjennomsnittlig var 13,3 år gamle. Dette tilsvarer fødselskohorten fra 1977. Av det opprinnelige utvalget på 1195 elever som var valgt til å delta $\mathrm{i}$ undersøkelsen, sa 77,6\% seg villige til å delta. En del elever falt fra underveis, men en del nye elever kom også med i undersøkelsen. I den foreliggende artikkelen baserer vi oss på data samlet inn i 1992, 1993 og 1995. Antall elever som deltok ved disse tre datainnsamlingene var 974, 791 og 781. Antall som deltok ved alle de tre undersøkelsene som inngår i analysene $i$ denne artikkelen er 607. Antallet som hadde svart på tilstrekkelig mange av spørsmålene til å bli med i AMOS-modellene var 551.

Datainnsamlingene foregikk hele tiden ved bruk av spørreskjema. Så lenge elevene fortsatt gikk på ungdomsskolen ble data samlet inn i klasserommet av personell fra Hemil-senteret. De datainnsamlingene som ble gjennomført etter avsluttet ungdomsskole ble gjort postalt.

I den foreliggende undersøkelsen bruker vi opplysninger om kjønn, depressivitet, egne røykevaner, foreldres røykevaner og foreldrenes yrke. Spørsmålene om røykevaner er i samsvar med standarder utarbeidet av Verdens helseorganisasjon. I de foreliggende analysene ble røyking på alle de tre tidspunktene kodet slik at $0=$ røyker ikke, 1 = røyker ukentlig eller sjeldnere, og 2 = røyker daglig. Opplysningene om foreldres røykevaner ble kombinert til en variabel med følgende kodeverdier: $0=$ ingen av foreldrene røyker, $1=$ en av foreldrene røyker, 2 = begge foreldrene røyker. Spørsmålene som er ment å måle depressivitet er hentet fra en skala utviklet av Alsaker og medarbeidere $(38,39)$ og er gjengitt i Appendiks A. Skalaens psykometriske egenskaper er beskrevet tidligere, og det er blant annet vist at den korrelerer høyt med The Centre for Epidemiological Studies Depression Scale (CES-D), noe som må tas som en indikasjon på at skalaen er valid (40). Elevenes svar på spørsmålene om foreldrenes yrke ble kodet etter Standard for nordisk yrkesklassifisering og forenklet til en tredelt indikator på sosioøkonomisk status der laveste funksjonærkategori ble slått sammen med ufaglært arbeider og gitt kodeverdien 1 , de to mellomste funksjonærkategoriene ble slått sammen med faglært arbeider og gitt kodeverdien 2, og høyeste funksjonærkategori fikk kodeverdien 3.

Dataene ble analysert ved bruk av krysstabellanalyse med khi-kvadrat-testing, variansanalyser (enveis og toveis), prinsipalkomponentanalyse og strukturelle ligningsmodeller (AMOS). På grunnlag av de syv leddene $\mathrm{i}$ depresjonsskalaen ble det laget en enkel, additiv sumskåre. For å ta vare på metrikken i den opprinnelige skalaen, ble summen dividert med antall ledd. Dermed kunne skårene variere fra 0-4.

Ved analyse av kovariansstrukturer er det blitt vanlig å benytte en to-trinns prosedyre. Denne framgangsmåten har vi brukt i den foreliggende artikkelen. Først tester en det som blir kalt målemodeller. Målemodeller viser hvordan et sett observerte variabler som inngår i 
en skala reflekterer en eller flere underliggende latente variabler. Deretter utvikler en modeller som beskriver sammenhenger mellom de latente variablene innbyrdes. Dette kalles strukturelle modeller. Strukturelle modeller kan også omfatte enkeltvariabler som er målt direkte, og som ikke antas å reflektere noen underliggende latent variabel.

Med tanke på å teste ut ulike strukturelle modeller fulgte vi en prosedyre der en starter med det som kalles den isolerte stabilitetsmodellen (41). Denne modellen spesifiserer en assosiasjon mellom variablene $\mathrm{X}$ og $\mathrm{Y}$ på tidspunkt $\mathrm{T}$ samt autoregresjonskoeffisientene for hver av de to variablene på tidspunkt $\mathrm{T}$ mot $\mathrm{T}+1, \mathrm{~T}+1$ mot $\mathrm{T}+2$ etc. Ingen av kryssregresjonskoeffisientene mellom $\mathrm{X}$ og $\mathrm{Y}$ inngår $\mathrm{i}$ denne modellen. Modellen kalles også en første ordens autoregressiv modell fordi bare sammenhenger mellom direkte etterfølgende tidspunkt inngår. Dwyer (42) og Rogosa (43) har begge slått fast at den isolerte stabilitetsmodellen representerer en nullhypotese som er viktig å ta utgangspunkt $\mathrm{i}$ før en kan underøke mulige kryssrelasjoner med tanke på å belyse mulig kausalitet mellom variablene $\mathrm{X}$ og Y.

Den isolerte stabilitetsmodellen innebærer at dersom ingen ytre faktorer virker systematisk inn, og dersom det ikke eksisterer noen kryssregresjonseffekter, vil sammenhengen mellom $\mathrm{X}$ og $\mathrm{Y}$ bli svakere for hvert nytt måletidspunkt (forutsatt at autoregresjonskoeffisientene er lavere enn 1,0). Dersom sammenhengene ikke blir lavere over tid, men forblir like sterke eller øker i styrke, betyr det at den ene av de to variablene påvirker den andre eller at de påvirker hverandre gjensidig. Det kan også være snakk om tredjevariabler utenfor modellen som fører til at korrelasjonen opprettholdes eller blir sterkere (41). Med utgangspunkt $i$ den isolerte stabilitetsmodellen er det derfor mulig å teste ut kryssregresjonseffekter (samtidige eller kryssforskjøvne) og kontrollere disse sammenhengene for mulige tredjevariabler.

Om en skal velge modeller med samtidige sammenhenger, tidsforskjøvne sammenhenger eller en kombinasjon av disse, er først og fremst avhengig av hva som rent teoretisk er mest meningsfylt. I vår unders $\varnothing-$ kelse er tidsavstanden mellom de to første målingene ett år og mellom den andre og den tredje målingen to år. Selv om depressivitet skulle vise seg å predikere røyking med en så stor grad av tidsforskyvning, kan det likevel tenkes at den optimale tidsforskyvningen er betydelig kortere. Med tanke på å undersøke sammenhengen mellom depressivitet og røyking kan det derfor være en god løsning å både se på samtidige og tidsforskjøvne sammenhenger. Vi har derfor valgt å prøve ut begge typer modeller.

Det ble vurdert å bruke polykoriske korrelasjoner som grunnlag for de strukturelle ligningsmodellene. Dette fordi flere av variablene som inngår må sies å være kategorielle ordinalvariabler og ikke intervallnivåvariabler. Yung \& Bentler (44) har imidlertid advart mot å bruke polykoriske korrelasjoner på så små datasett som det foreliggende. De foreliggende analysene er derfor basert på bruk av Pearsons r. Sammenhengene mellom variablene som inngår $\mathrm{i}$ analysene er tilnærmet lineære.

Ved utprøving av modeller benyttet vi "maximum likelihood"-estimering.

\section{Resultater}

Det ble gjort analyser med tanke på å belyse konsekvensene av frafallet i undersøkelsen fra 1992 til 1993 og fra 1992 til 1995. Blant de som hadde deltatt i 1992 men som ikke deltok i 1993 var skåren på depressivitet signifikant høyere enn blant de som fortsatt deltok i 1993 (eta $=0,14, \mathrm{~F}=20,96$; f.g. $=1$ og 912; $<<0,001)$. Deltakelse i 1995 hadde imidlertid ingen signifikant sammenheng med depressivitet i 1992 (eta $=0,04)$. Blant de som hadde deltatt i 1992 men ikke deltok i 1993 var andel dagligrøykere lavere (15\%) enn blant de som fortsatt var med i 1993 (28\%) (Khi kvadrat = 16,56; f.g. $=1 ; \mathrm{p}<0,001)$. Blant de som fortsatt var med i 1995 var andel dagligrøykere i 1992 15\%, mot $23 \%$ blant de som ikke var med i 1995 (Khi kvadrat = $8,98$; f.g. $=1 ; \mathrm{p}<0,01)$.

Toveis variansanalyser med depressivitet som avhengig variabel og kjønn og røyking som uavhengige variabler på hvert av de tre tidspunktene viste ingen signifikante interaksjonseffekter. For enkelhets skyld, og for å beholde mest mulig av styrken (power) i de statistiske analysene, ble det derfor bestemt å analysere dataene for gutter og jenter samlet.

Tabell 1 viser gjennomsnittlig skåre på depresjonsskalaen etter røykevaner. På alle tre tidspunkt skårer ikke-røykerne lavest på depressivitet og dagligrøykerne skårer høyest. Forskjellen varierer mellom $0,37 \mathrm{og}$ 0,46 standardavvik. Styrken på sammenhengen målt ved bruk av eta-koeffisienten er 0,24 i 1992, og 0,21 på de to siste tidspunktene.

Siden antallet som røyker daglig og antallet som røyker sjeldnere enn daglig på hvert av de tre tidspunktene var nokså lavt, slo en sammen disse gruppene før dataene ble analysert i AMOS. Dermed ble også sammenhengen mellom røyking og depressivitet tilnærmet lineær.

Innledningsvis prøvde vi ut en enkel målemodell for depresjonsskalaen på hvert av de tre tidspunktene. I denne målemodellen lot vi alle de syv leddene reflektere en enkelt underliggende (latent) variabel. Comparative Fit Index (CFI) var $0,92,0,94$, og 0,85 på de tre tidspunktene, og RMSEA var 0,16, 0,11 og 0,21. Dette er ikke helt tilfredsstillende resultater. CFI burde være noe høyere og RMSEA noe lavere. Det viste seg at på alle tre tidspunkt kunne målemodellen bedres mye ved å la noen residualtermer korrelere, nærmere bestemt første og syvende samt tredje og femte ledd i skalaen (se Appendiks A). CFI økte da til 0,97, 0,98 og 0,99 for de tre tidspunktene, mens RMSEA ble redusert til 0,07, 0,06 og 0,11. Disse verdiene er langt mer akseptable. 
Tabell 1. Depressivitet (sumskåre) etter røykevaner, separat for tre tidspunkt (1992, 1993 og 1995).

\begin{tabular}{|c|c|c|c|c|c|c|c|c|c|}
\hline \multirow[b]{2}{*}{ Røyker ${ }^{1} \ldots$} & \multicolumn{3}{|c|}{$\begin{array}{c}1992 \\
\text { Depressivitet }\end{array}$} & \multicolumn{3}{|c|}{$\begin{array}{c}1993 \\
\text { Depressivitet }\end{array}$} & \multicolumn{3}{|c|}{$\begin{array}{c}1995 \\
\text { Depressivitet }\end{array}$} \\
\hline & $\mathrm{x}$ & SD & $\mathrm{n}$ & $\mathrm{x}$ & SD & $\mathrm{n}$ & $\mathrm{x}$ & SD & $\mathrm{n}$ \\
\hline Daglig & 1,85 & 1,27 & 160 & 1,52 & 1,20 & 154 & 1,70 & 1,19 & 241 \\
\hline Ukentlig & 1,87 & 1,18 & 51 & 1,11 & 0,88 & 33 & 1,20 & 0,80 & 47 \\
\hline Sjeldnere & 1,44 & 0,92 & 108 & 1,34 & 1,02 & 55 & 1,43 & 1,02 & 83 \\
\hline Røyker ikke & 1,23 & 0,99 & 583 & 1,00 & 0,97 & 464 & 1,19 & 1,01 & 403 \\
\hline Total & 1,40 & 1,08 & 902 & 1,14 & 1,05 & 706 & 1,38 & 1,08 & 774 \\
\hline
\end{tabular}

$\mathrm{F}_{(1992)}=18,25 ;$ f.g. $=3,898 ; \mathrm{p}<0,001 ;$ eta $=0,24$

$\mathrm{F}_{(1993)}=10,64 ;$ f.g. $=3,702 ; \mathrm{p}<0,001 ;$ eta $=0,21$

$\mathrm{F}_{(1995)}=12,02 ;$ f.g. $=3,770 ; \mathrm{p}<0,001 ;$ eta $=0,21$

${ }^{1}$ Depressivitet er analysert mot røykevaner slik de ble målt ved samme datainnsamling

Siden det var noe usikkerhet omkring hvilken målemodell som var mest egnet i den foreliggende analysen, ble det også gjort en prinsipalkomponentanalyse av leddene i depressivitetsskalaen for hvert tidspunkt. Alle de tre analysene viste at bare en komponent fikk eigenverdi (eigenvalue) større enn 1,0 (3,8, 4,3 og 4,5 for de tre årene). I alle tre tilfellene hadde komponent nr. 2 en eigenverdi som var under 0,9. Dette bekrefter at skalaen best kan beskrives som endimensjonal.

Forsøk som ble gjort på å analysere sammenhengen mellom depressivitet og røyking basert på de forbedrede målemodellene gav samme resultater som analyser der en brukte de opprinnelige målemodellene. For å gjøre analysen så enkel som mulig, ble det besluttet å bruke de enkleste målemodellene.
Analysene i AMOS resulterte i to ulike modeller som passer omtrent like godt med dataene. Modellene er presentert i figur 1 og 2, og statistikken som viser egenskapene ved disse modellene er vist i tabell 2 og 3. Begge modeller viser en CFI på 0,86 og en RMSEA på 0,090 . Forskjellen mellom de to modellene når det gjelder verdiene på Akaike Information Criterion (AIC), som benyttes når en skal sammenlikne modeller som ikke er nøstede (nested), går svakt i favør av modellen vist $\mathrm{i}$ figur 1 ( $\mathrm{AIC}=1448,5$ og 1452,9). Begge modellene er betydelig bedre enn den isolerte stabilitetsmodellen som gav en AIC-verdi på 1470,67.

I tabell 2 og 3 vises effekten av å fjerne sammenhenger som inngår i modellene eller legge til sammenhenger som ikke inngår. Alle de forbindelseslinjene

Tabell 2. Røyking og depressivitet. Strukturelle likningsmodeller (AMOS). Testing av modell vist i figur 1.

\begin{tabular}{ccccccccc}
\hline Modell & $\chi^{2}$ & f.g. & AIC & RMSEA & CFI & $\Delta \chi^{2}$ & f.g. & $\mathrm{p}<$ \\
\hline $1^{1}$ & 1344,456 & 248 & 1448,456 & 0,090 & 0,860 & & & \\
2 & 1366,444 & 249 & 1468,444 & 0,090 & 0,857 & 21,988 & 1 & 0,001 \\
3 & 1353,026 & 249 & 1455,026 & 0,090 & 0,859 & 8,570 & 1 & 0,01 \\
4 & 1362,067 & 249 & 1464,067 & 0,090 & 0,858 & 17,611 & 1 & 0,001 \\
5 & 1343,417 & 247 & 1449,417 & 0,090 & 0,860 & 1,039 & 1 & n.s. \\
6 & 1343,568 & 247 & 1449,568 & 0,090 & 0,860 & 0,888 & 1 & n.s. \\
7 & 1344,314 & 247 & 1450,314 & 0,090 & 0,860 & 0,142 & 1 & n.s. \\
8 & 1343,522 & 247 & 1449,522 & 0,090 & 0,860 & 0,934 & 1 & n.s. \\
9 & 1344,436 & 247 & 1450,436 & 0,090 & 0,860 & 0,020 & 1 & n.s. \\
10 & 1343,344 & 247 & 1449,344 & 0,090 & 0,860 & 1,112 & 1 & n.s. \\
11 & 847,553 & 242 & 963,553 & 0,067 & 0,923 & & & \\
\hline
\end{tabular}

${ }^{1}$ Modell 1 som vist på figur 1

Modell 2: Som modell 1, men uten forbindelsen mellom Depressivitet 1992 og Røyking 1992

Modell 3: Som modell 1, men uten forbindelsen fra Depressivitet 1993 til Røyking 1993

Modell 4: Som modell 1, men uten forbindelsen fra Depressivitet 1995 til Røyking 1995

Modell 5: Som modell 1, men i tillegg forbindelsen fra Røyking 1993 til Depressivitet 1993

Modell 6: Som modell 1, men i tillegg forbindelsen fra Røyking 1995 til Depressivitet 1995

Modell 7: Som modell 1, men i tillegg forbindelsen fra Depressivitet 1992 til Røyking 1993

Modell 8: Som modell 1, men i tillegg forbindelsen fra Røyking 1992 til Depressivitet 1993

Modell 9: Som modell 1, men i tillegg forbindelsen fra Depressivitet 1993 til Røyking 1995

Modell 10: Som modell 1, men i tillegg forbindelsen fra Røyking 1993 til Depressivitet 1995

Modell 11: Som modell 1, men i tillegg forbindelser mellom 1. og 7. samt 3. og 5. observerte variabel i hver målemodell 
Tabell 3. Røyking og depressivitet. Strukturelle likningsmodeller (AMOS). Testing av modell vist i figur 2.

\begin{tabular}{ccccccrcl}
\hline Modell & $\chi^{2}$ & f.g. & \multicolumn{1}{c}{ AIC } & RMSEA & CFI & $\Delta \chi^{2}$ & f.g. & $\mathrm{p}<$ \\
\hline $1^{1}$ & 1346,940 & 247 & 1452,940 & 0,090 & 0,860 & & & \\
2 & 1368,930 & 248 & 1472,930 & 0,091 & 0,857 & 21,990 & 1 & 0,001 \\
3 & 1353,017 & 248 & 1457,017 & 0,090 & 0,859 & 6,077 & 1 & 0,05 \\
4 & 1356,691 & 248 & 1460,691 & 0,090 & 0,858 & 9,751 & 1 & 0,01 \\
5 & 1357,631 & 248 & 1457,631 & 0,090 & 0,859 & 10,691 & 1 & 0,01 \\
6 & 1344,293 & 246 & 1452,293 & 0,090 & 0,860 & 2,647 & 1 & n.s. \\
7 & 1345,935 & 246 & 1453,935 & 0,090 & 0,860 & 1,005 & 1 & n.s. \\
8 & 1345,855 & 246 & 1453,855 & 0,090 & 0,860 & 1,085 & 1 & n.s. \\
9 & 850,499 & 241 & 968,499 & 0,068 & 0,922 & & & \\
\hline
\end{tabular}

${ }^{1}$ Modell 1 som vist på figur 2

Modell 2: Som modell 1, men uten forbindelsen mellom Depressivitet 1992 og Røyking 1992

Modell 3: Som modell 1, men uten forbindelsen mellom feiltermene til Depressivitet 1993 og Røyking 1993

Modell 4: Som modell 1, men uten forbindelsen mellom feiltermene til Depressivitet 1995 og Røyking 1995

Modell 5: Som modell 1, men uten forbindelsen fra Depressivitet 1993 til Røyking 1995

Modell 6: Som modell 1, men i tillegg forbindelsen fra Depressivitet 1992 til Røyking 1993

Modell 7: Som modell 1, men i tillegg forbindelsen fra Røyking 1992 til Depressivitet 1993

Modell 8: Som modell 1, men i tillegg forbindelsen fra Røyking 1993 til Depressivitet 1995

Modell 9: Som modell 1, men i tillegg forbindelser mellom 1. og 7. samt 3. og 5. observerte variabel i hver målemodell

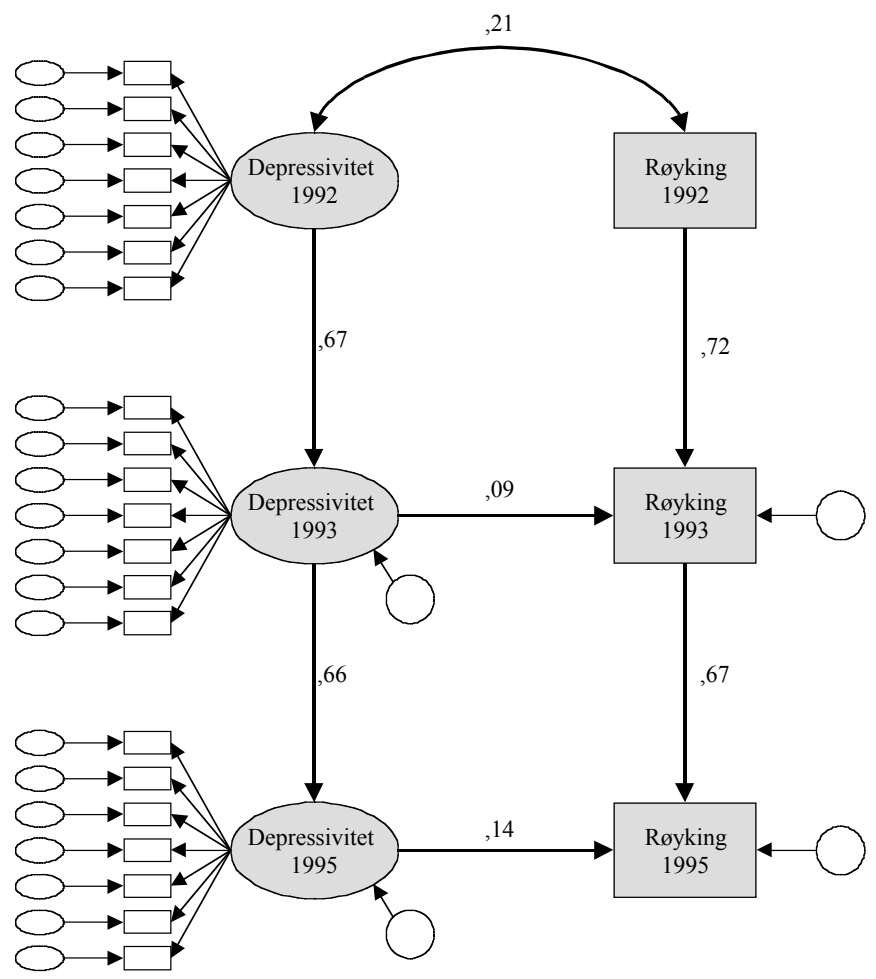

Figur 1. Strukturell ligningsmodell over sammenhengen mellom depressivitet og røykevaner (AMOS).

mellom depressivitet og røyking som er med i modellene er statistisk signifikante. Ingen av de forbindelseslinjene mellom depressivitet og røyking som er utelatt fra modellene er signifikante. Den siste modellen som vises $i$ hver av tabellene inneholder den forbedringen av målemodellene som er beskrevet ovenfor (spesifikasjon av sammenhenger mellom residualer på enkeltledd i depressivitetsskalaen). Denne justeringen gir i begge tilfeller akseptabel statistikk på tilpasning mellom modell og data (fit). De forbedrede modellene gir
CFI-verdier på 0,923 og 0,922 og RMSEA-verdier på 0,067 og 0,068 . De forskjellene som finnes går svakt $\mathrm{i}$ favør av modellen som presenteres i figur 1.

Det interessante er at $\mathrm{i}$ begge modellene inngår signifikante forbindelser fra depressivitet til røyking, men ingen forbindelser motsatt vei. Dette er en indikasjon på at, selv om sammenhengene er ganske svake, er det depressivitet som virker inn på røyking og ikke motsatt. Det er også interessant å legge merke til at i figur 1 er sammenhengen mellom depressivitet og 


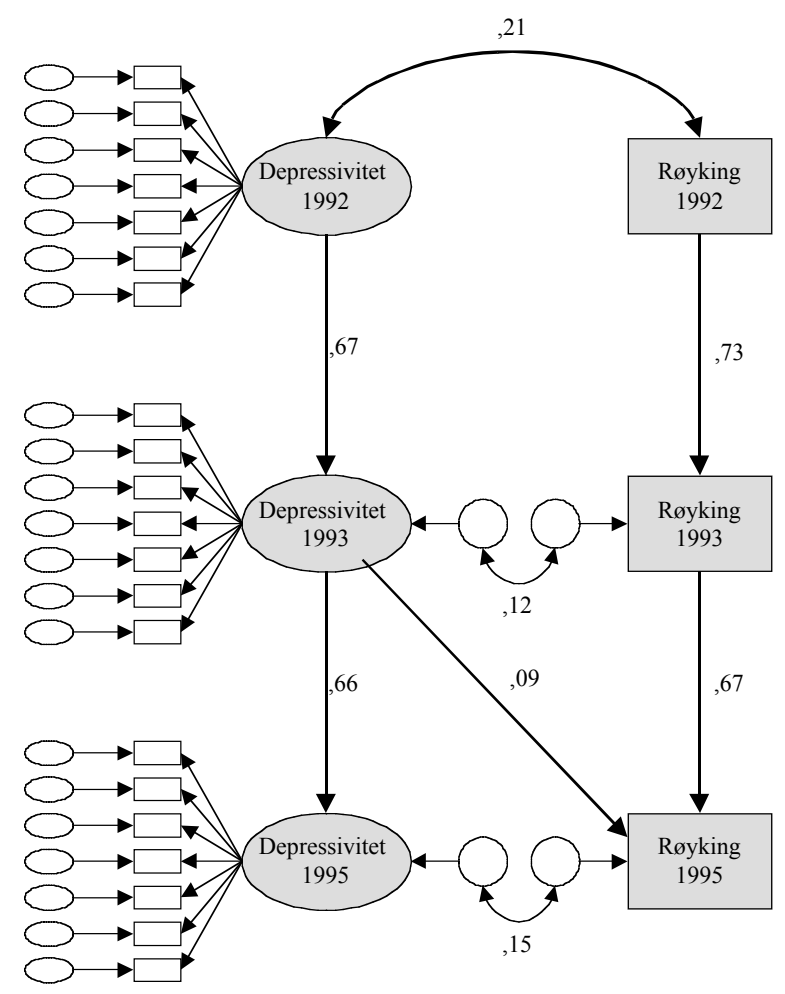

Figur 2. Strukturell ligningsmodell over sammenhengen mellom depressivitet og røykevaner (AMOS).

røyking noe sterkere i 1995 enn i 1993. Dessuten viser modellen i figur 2 at sammenhengen mellom Depressivitet 1992 og Røyking 1993 ikke er signifikant, mens sammenhengen mellom Depressivitet 1993 og Røyking 1995 er signifikant. Begge modellene er med andre ord konsistente med en antakelse om at depressivitet er en viktigere risikofaktor for røyking jo eldre en blir. Dersom sammenhengen mellom Depressivitet 1993 og Røyking 1995 tas inn i modellen, blir den standardiserte regresjonskoeffisienten 0,05 , og forskjellen mellom modellene grensesignifikant $(\mathrm{p}=0,10)$.

Modellene viser også den relative stabiliteten i depressivitet og røyking. Assosiasjonen mellom Depressivitet 1992 og Depressivitet 1993 er i begge modellene 0,67 , mens tilsvarende sammenheng fra 1993 til 1995 er på 0,66. At assosiasjonen i løpet av de to årene fra 1993 til 1995 er omtrent like høy som assosiasjonen mellom de to første målingene, som bare er gjort med ett års mellomrom, tyder på at den relative stabiliteten reelt har økt. Sammenhengene når det gjelder røyking over de tre måletidspunktene gir et nokså tilsvarende bilde.

De to modellene som er gjengitt i figurene ble modifisert ved at foreldres røykevaner og foreldres sosioøkonomiske status ble satt inn som prediktorer av både røyking og depressivitet på alle tre tidspunkt samtidig. Dette førte ikke til noen endringer i modellene. De signifikante kryssregresjonskoeffisientene som var med i de opprinnelige modellene var fortsatt signifikante, og de som ikke inngikk oppnådde heller ikke nå signifikans.

\section{DISKUSJON}

De viktigste resultatene kan summeres opp punktvis:

- Depressivitetsskalaen er tilnærmet endimensjonal.

- På hvert tidspunkt er det en signifikant og moderat sammenheng mellom depressivitet og røyking.

- Denne sammenhengen er ikke signifikant forskjellig for gutter og jenter.

- Stabiliteten er høy både når det gjelder depressivitet og røyking, og den øker sannsynligvis med alderen.

- De to strukturelle ligningsmodellene som ble utviklet tyder begge på at det først og fremst er depressivitet som er årsak til røyking og ikke motsatt.

- Begge modellene antyder at depressivitet blir viktigere som årsak til røyking etter hvert som ungdommene blir eldre.

- Kontroll for foreldres røyking og for sosioøkonomisk status gav ingen endringer i kryssregresjonseffektene.

Når modellene gir omtrent like god tilpasning, kan det være et tegn på at ingen av modellene er helt optimale. Årsaken til dette kan være at tidsavstanden mellom målingene er for stor. Det er sannsynligvis ikke realistisk å anta at depressivitet på ett tidspunkt slår særlig sterkt ut i økt røyking hele ett eller to år senere. Dersom det eksisterer en optimal tidsforskyvning (lag), er det rimeligere å regne med at den er langt kortere, kanskje bare noen få måneder. Når modellen med samtidige sammenhenger er marginalt bedre enn modellen med forskjøvne sammenhenger, kan dette 
tolkes som en indikasjon på at datainnsamlingene burde ha kommet med kortere mellomrom. Vi kan heller ikke se bort fra at sammenhengen så å si er samtidig. For å belyse dette nærmere ville det være fordelaktig med langt hyppigere målinger, kanskje hver 3 måned.

At kausaliteten er såpass entydig som vist ovenfor, er overraskende sett i lys av tidligere forskning. Nokså mange studier har nemlig konkludert med at kausaliteten går begge veier $(25,26,33,34)$, og en del forskere har hevdet at denne gjensidige kausaliteten egentlig kan være uttrykk for at det eksisterer bakenforliggende forhold som er årsak både til depressivitet og røyking. Vår undersøkelse tyder på at depressivitet i noen grad kan være en årsak til at ungdom røyker, i hvert fall når de nærmer seg siste del av tenårene. Selv om det å begynne å røyke først og fremst må betraktes som et resultat av sosiale påvirkninger, kan det godt tenkes, slik som Patton og medarbeidere (31) hevder, at de som utvikler depressivitet er mer påvirkelige til å begynne å røyke.

Den forholdsvis klare sammenhengen mellom depressivitet og røyking som er vist $i$ de bivariate tverrsnittsanalysene er også verdt å legge merke til, for det er langt fra alle studier som har klart å påvise en slik sammenheng i det hele tatt. At ulike studier har kommet til ulike konklusjoner, kan selvsagt skyldes forskjeller i metode. Dersom en bruker instrumenter med lavere reliabilitet enn de vi har brukt her, eller dersom antall observasjoner som inngår $i$ analysene er lavere, vil det være vanskeligere å påvise sammenhenger. Men det finnes også mer substansielle forklaringer. Det er sannsynlig at de faktorene som bidrar til å påvirke ungdoms røykevaner endrer seg systematisk over tid. Dersom vi går tilstrekkelig langt tilbake i tid, vil vi finne at røyking var mest utbredt $i$ høystatusgrupper $i$ samfunnet. Røyking var et symbol på at en var vellykket. I dag er sammenhengen mellom sosioøkonomisk status en helt annen. Blant de som har høyere utdannelse er det svært lite røyking, og røyking blant ungdom har fått en langt mer negativ symbolverdi enn tidligere. Denne forskjellen handler ikke bare om tid, men også om geografi. Mens tobakksrøykingen er på jevn tilbakegang i de vestlige land, øker tobakksomsetningen fremdeles i mange utviklingsland og i ØstEuropa. Når en ganske fersk undersøkelse fra Slovenia (20) på et langt større datamateriale enn det foreliggende ikke var $\mathrm{i}$ stand til å påvise noen statistisk sikker sammenheng mellom depressivitet og røyking, kan årsaken nettopp være at røyking i deres kulturkrets fremdeles har en helt annen status og symbolverdi enn i Vesten.

Mens en i flere tidligere studier har funnet forskjeller mellom gutter og jenter når det gjelder sammenhengen mellom depressivitet og røyking (14-16), kan dette også handle om kulturelle forskjeller. Her i landet er forskjellen i røykevaner mellom gutter og jenter og unge menn og unge kvinner svært liten. I aldersgruppen 16-24 år har nedgangen i andel som røyker vært nesten helt parallell siden 1970-tallet. Blant ungdomsskole- elever har kjønnsforskjellene $\mathrm{i}$ andel som røyker lenge vært ganske liten. Sosiale påvirkningsfaktorers sammenheng med ungdoms røykevaner har også vist seg å være ganske like på tvers av kjønn. Det er derfor ikke overraskende å finne at sammenhengene mellom depressivitet og røyking også er nokså like for gutter og jenter.

Selv om resultatene fra den foreliggende undersøkelsen tyder på at depressivitet bidrar til at flere røyker, er det viktig å legge merke til at sammenhengene, slik de framkommer i de strukturelle ligningsmodellene, tross alt er ganske svake. Blant yngre ungdommer må vi regne med at depressivitet spiller en helt underordnet rolle som årsak til røyking. Blant eldre ungdom betyr sannsynligvis depressivitet noe mer, og kanskje er betydningen enda større blant voksne. Noen studier har vist at de som skårer høyt på depressivitet eller de som har fått en depresjonsdiagnose har vanskeligere for å slutte enn andre $(2,6)$. Konsekvensen av dette er sannsynligvis at sammenhengen mellom depressivitet og røyking blir sterkere med alderen også blant voksne. Depressivitet er derfor sannsynligvis viktigere å ta $\mathrm{i}$ betraktning når en driver røykeavvenningstiltak blant voksne enn når en planlegger tiltak for å hindre ungdom i å begynne å røyke.

I de foreliggende analysene har vi kontrollert for foreldrenes røykevaner og foreldrenes sosioøkonomiske status uten at dette endret noe på resultatene. Dermed har vi ikke bare analysert dataene med tanke på å belyse kausalitet, men vi har også vist at kontroll for to potensielt viktige tredjevariabler ikke har svekket våre funn.

Analysene kan videreføres ved at en mer systematisk undersøker om det finnes modererende faktorer. En del slike er påvist i tidligere studier. Her har vi bare sett på kjønn som moderator. Det ville være interessant å se om venners røyking, foreldres røyking eller andre forhold interagerer med depressivitet. Dette er det samme som å undersøke om sammenhengen mellom depressivitet og røyking er sterkere i noen grupper enn $\mathrm{i}$ andre grupper. Et alternativ til de modellene som presenteres her er bruk av latente vekstkurveanalyser. Fordelen med disse er blant annet at en kan se på hvordan veksten $i$ en variabel som viser en økning over tid (for eksempel røyking blant ungdom) kan predikeres. Dette er noe vi må komme tilbake til i framtidige publikasjoner.

Kausalmodellene er utviklet på grunnlag av analyser av data fra den delen av elevene som deltok ved alle tre undersøkelsene og som dessuten hadde svart på de fleste av de spørsmålene som inngår i analysene. Dette fører til at antall observasjoner er betydelig lavere enn det opprinnelige utvalget av elever. De som faller ut av undersøkelsen skårer høyere på depressivitet enn de som fortsatt er med (signifikant for 1993) og de som faller ut røyker mer (signifikant både i 1993 og i 1995). Resultatet av frafallet er en redusert spredning både på spørsmålene om røykevaner og på depressivitetsskalaen. Konsekvensene av slik redusert spredning 
på variablene er vanligvis at sammenhengene i modellene blir noe svakere enn de hadde blitt med et mindre frafall. Med et mindre frafall er det derfor sannsynlig at sammenhengene i modellen hadde blitt noe sterkere.

Appendiks A. Spørsmål brukt for å måle depressivitet (etter Alsaker \& Olweus, 1991; Alsaker, 1992).

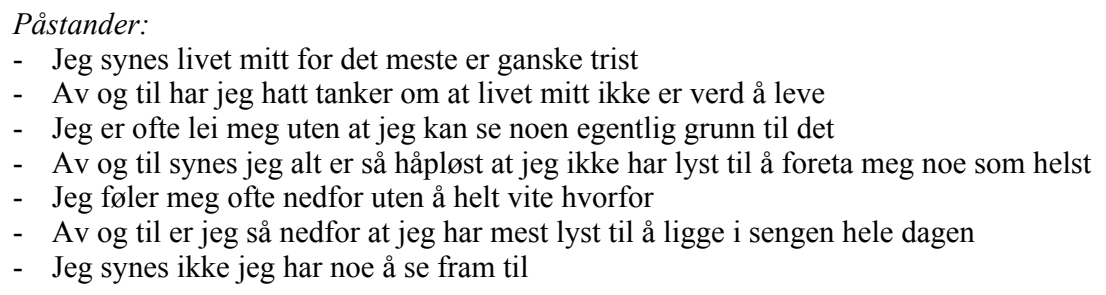

Svarkategorier:

Stemmer helt Stemmer noenlunde

Stemmer godt Stemmer ikke særlig godt

Stemmer ganske godt Stemmer ikke i det hele tatt

\section{REFERANSER}

1. Conrad KM, Flay BR, Hill D. Why children start smoking cigarettes: predictors of onset. Br J Addict 1992; 87: 1711-24.

2. Anda RF, Williamson DF, Escobedo LG, Mast EE, Giovino GA, Remington PL. Depression and the dynamics of smoking: a national perspective. J Am Med Assoc 1990; 264: 1541-5.

3. Breslau N, Kilbey MM, Andreski P. Nicotine dependence, major depression, and anxiety in young adults. Arch Gen Psychiatry 1991; 48: 1069-74.

4. Lerman C, Audrain J, Orleans CT, Boyd R, Gold K, Main D, Caporaso N. Investigation of mechanisms linking depressed mood to nicotine dependence. Addict Behav 1996; 21: 9-19.

5. Hughes JR, Hatsukami DK, Mitchell JE, Dahlgren LA. Prevalence of smoking among psychiatric outpatients. Am J Psychiatry 1968; 143: 993-7.

6. Glassman AH, Helzer JE, Covey LS, Cottler LB, Stetner F, Tipp JE, Johnson J. Smoking, smoking cessation, and major depression. J Am Med Assoc 1990; 264: 1546-9.

7. Coogan PF, Adams M, Geller AC, Brooks D, Miller DR, Lew RA, Koh HK. Factors associated with smoking among children and adolescents in Connecticut. Am J Prev Med 1998; 15: 17-24.

8. Cornelius JR, Lynch K, Martin CS, Cornelius MD, Clark DB. Clinical correlates of heavy tobacco use among adolescents. Addict Behav 2001; 26: 273-7.

9. Covey LS, Tam D. Depressive mood, the single-parent home, and adolescent cigarette smoking. Am J Public Health 1990; 80: 1330-3.

10. Fergusson DM, Lynskey MT, Horwood LJ. Comorbidity between depressive disorders and nicotine dependence in a cohort of 16-year-olds. Arch Gen Psychiatry 1996; 53: 1043-7.

11. Kaplan SL, Landa B, Weinhold C, Shenker IR. Adverse health behaviors and depressive symptomatology in adolescents. J Am Acad Child Psychiatry 1984; 23: 595-601.

12. Wang MQ, Fitzhugh EC, Westerfield RC, Eddy JM. Predicting smoking status by symptoms of depression for U.S. adolescents. Psychol Rep 1994; 75: 911-4.

13. Costello EJ, Erkanli A, Federman E, Angold A. Development of psychiatric comorbidity with substance abuse in adolescents: Effects of timing and sex. J Clin Child Psychol 1999; 28: 298-311.

14. Hawkins WE, Hawkins MJ, Seeley J. Stress, health-related behavior and quality of life on depressive symptomatology in a sample of adolescents. Psychol Rep 1992; 71: 183-6.

15. Pesa JA, Cowdery JE, Wang MQ, Fu Q. Self-reported depressive feelings and cigarette smoking among Mexican-American adolescents. J Alcohol Drug Educ 1997; 43: 63-75.

16. Whalen CK, Jamner LD, Henker B, Delfino RJ. Smoking and moods in adolescents with depressive and aggressive dispositions: Evidence from surveys and electronic diaries. Health Psychol 2001; 20: 99-111.

17. Acierno R, Kilpatrick DG, Resnick H, Saunders B, De Arellano M, Best C. Assault, PTSD, family substance use, and depression as risk factors for cigarette use in youth: findings from the national survey of adolescents. J Traum Stress 2000; 13: 381-96.

18. Malkin SA, Allen DL. Differential characteristics of adolescent smokers and non-smokers. J Fam Pract 1980; 10: $437-40$ 
19. Strønstad K. Sammenhengen mellom depressivitet og røyking. En prospektiv undersøkelse blant ungdom i Hordaland. Bergen: Universitetet i Bergen, Institutt for samfunnspsykologi og Hemil-senteret (Hovedoppgave i psykologi), 2002.

20. Tomori M, Zalar B, Kores PB, Ziherl S, Stergar E. Smoking in relation to psychosocial risk factors in adolescents. Eur Child Adolesc Psychiatry 2001; 10: 143-50.

21. Lavik NJ, Onstad S. Drug use and psychiatric symptoms in adolescence. Acta Psychiatr Scand 1986; 73: 43740 .

22. Kendler KS, Neale MC, MacLean CJ, Heath AC, Eaves LJ, Kessler RC. Smoking and major depression. A causal analysis. Arch Gen Psychiatry 1993; 50: 36-43.

23. Giovino GA, Henningfield JE, Tomar SL, Escobedo LG, Slade J. Epidemiology of tobacco use and dependence. Epidemiol Rev 1995; 17: 48-65.

24. Bardone AM, Moffitt TE, Caspi A, Dickson N, Stanton WR, Silva PA. Adult physical health outcomes of adolescent girls with conduct disorder, depression, and anxiety. J Am Acad Child Adolesc Psychiatry 1998; 37: 594-601.

25. Breslau N, Peterson EL, Schultz LR, Chilcoat HD, Andreski P. Major depression and stages of smoking: A longitudinal investigation. Arch Gen Psychiatry 1998; 55: 161-6.

26. Brown RA, Lewinsohn PM, Seeley JR, Wagner EF. Cigarette smoking, major depression, and other psychiatric disorders among adolescents. J Am Acad Child Adolesc Psychiatry 1996; 35: 1602-10.

27. Ebeling H, Moilanen I, Linna S-L, Tirkkonen T, Ebeling T, Piha J, Kumpulainen K, Räsänen E, Tamminen T, Almqvist F. Smoking and drinking habits in adolescence. Links with psychiatric disturbance at the age of 8 years. Eur Child Adolesc Psychiatry 1999; 8 (Suppl 4): IV/68-IV/76.

28. Escobedo LG, Reddy M, Giovino GA. The relationship between depressive symptoms and cigarette smoking in US adolescents. Addiction 1998; 93: 433-40.

29. Kandel DB, Davies M. Adult sequelae of adolescent depressive symptoms. Arch Gen Psychiatry 1986; 43: 255-62.

30. Killen JD, Robinson TN, Haydel KF, Hayward C, Wilson DM, Hammer LD, Litt IF, Barr Taylor C. Prospective study of risk factors for the initiation of cigarette smoking. J Consult Clin Psychol 1997; 65: 1011-6.

31. Patton GC, Carlin JB, Coffey C, Wolfe R, Hibbert M, Bowes G. Depression, anxiety and smoking initiation: A prospective study over 3 years. Am J Public Health 1998; 88: 1518-22.

32. Rohde P, Lewinsohn PM, Seeley JR. Are adolescents changed by an episode of major depression? J Am Acad Child Psychiatry 1994; 33: 1289-98.

33. Wang MQ, Fitzhugh EC, Turner L, Fu Q, Westerfield RC. Associations of depressive symptoms and school adolescents' smoking: A cross-lagged analysis. Psychol Rep 1996; 79: 127-30.

34. Windle M, Windle RC. Depressive symptoms and cigarette smoking among middle adolescents: Prospective associations and intrapersonal iand interpersonal influences. J Consult Clin Psychol 2001; 69: 215-26.

35. Miller-Johnson S, Lochman JE, Coie JD, Terry R, Hyman C. Comorbidity of conduct and depressive problems at sixth grade: Substance use outcomes across adolescence. J Abnorm Child Psychol 1998; 26: 221-32.

36. Choi WS, Patten CA, Gillin JC, Kaplan RM, Pierce JP. Cigarette smoking predicts development of depressive symptoms among U.S. adolescents. Ann Behav Med 1997; 19: 42-50.

37. Pomerleau OF, Pomerleau CS. Neuroregulators and the reinforcement of smoking: Towards a biobehavioral explanation. Neurosci Biobehav Rev 1984; 8: 503-13.

38. Alsaker FD, Dundas I, Olweus D. A growth curve approach to the study of parental relations and depression in adolescence. I: Hops H. Contextual relationship and parenting predictors of child/adolescent adustment: Multi-agent, multi-method approaches. Symposium at the Biennial Meeting of the Society for Research in Child Development, Seattle, USA. Bergen: University of Bergen (Research Report), 1991.

39. Alsaker FD. Pubertal timing, overweight, and psychological adjustment. J Early Adolesc 1992; 12: 396-419.

40. Holsen I, Kraft P, Vittersø J. Stability in depressed mood in adolescence: results from a 6-year longitudinal panel study. J Youth Adolesc 2000; 29: 61-78.

41. Hertzog C, Nesselroade JR. Beyond autoregressive models: Some implications for the trait-state distinction for the structural modeling of developmental change. Child Dev 1987; 58: 93-109.

42. Dwyer JH. Statistical models for the social and behavioral sciences. New York: Oxford University Press, 1983.

43. Rogosa D. Causal models in longitudinal research: Rationale, formulation, and interpretation. I: Nesselroade JR, Baltes PB, red. Longitudinal research in the study of behavior and development. New York: Academic Press, 1979: 263-302.

44. Yung YF, Bentler PM. Bootstrap-corrected ADF test statistics in covariance structure analysis. Br $J$ Math Statist Psychol 1994; 47: 63-84. 